rare and this is especially so in the case of rhabdomyosarcoma of the heart. Clinical diagnosis of this condition has not been recorded, and diagnosis before death would depend on the condition causing symptoms brought about by interference with cardiac mechanism. The tumour described in this report was a silent one.

\section{Acknowledgment}

I wish to thank Dr D. C. Watler, Director, Government Medical Laboratory for his encouragement to write this paper and the Chief Medical Officer, Ministry of Health, for allowing me to publish this paper.

\section{References}

Anderson, W.A.D. (1971) Pathology, 6th Edn, pp. 578-687. Mosby Co., U.S.A.

Gould, S.E. (1968) Pathology of Heart and Blood-Vessels, 3rd Edn, p. 876. Charles C. Thomas, Springfield, Illinois.

Hardin, N.J.H., Wilson III, J.M., Gray, G.F. \& GaY, W.A., JR (1974) Experience with primary tumors of the heart. Clinical and pathological study of 17 cases. Johns Hopkins Medical Journal, 134, 141.

PrichaRd, R. (1951) Tumors of the heart. Review of the subject and report of 150 cases. Archives of Pathology, 51, 98.

Straus, R. \& Merliss, R. (1945) Primary tumor of heart. Archives of Pathology, 39, 74.

\title{
Aplasia of the right lung and calcifying epithelioma in association with Goldenhar's syndrome
}

\author{
M. M. KENAWI* \\ M.Ch., F.R.C.S.Ed., F.R.C.S. \\ J. A. S. DicksON \\ F.R.C.S. Ed.,F.R.C.S. \\ *The Hospital for Sick Children, Great Ormond Street, London WCIN 3JH, and \\ Department of Paediatric Surgery, 30 Guilford Street, London WCIN IEH
}

\begin{abstract}
Summary
A case of Goldenhar's syndrome (oculoauriculovertebral dysplasia) with the rare association of aplasia of one lung is presented with a discussion of the clinical findings and the aetiology. The major abnormalities, pulmonary, renal and the undergrowth of the jaw were all right-sided, confirming previous reports. This child developed a calcifying epithelioma and this is cited as support for the theory of the origin of these lesions from epidermoid cysts.
\end{abstract}

\section{Introduction}

Goldenhar's syndrome (1952) or oculoauriculovertebral dysplasia is a complex syndrome with ocular, auricular, oral and musculoskeletal features (Magalini, 1971). Cardiac anomalies occur occasionally but aplasia of the lung has been reported only once before (Gorlin et al., 1963). Although epibulbar dermoid cysts are frequent, this is the first reported association with a calcifying epithelioma of Malherbe.

\footnotetext{
* Present address: Cardiothoracic Surgery Registrar, The London Chest Hospital, Bonner Road, London E2 9JX.
}

\section{Case report}

M.M. presented to the Hospital for Sick Children, Great Ormond Street, London, at the age of 3 months with dyspnoea, recurrent cough and poor feeding, and failure to thrive. Her weight was only $3.4 \mathrm{~kg}$ (below $3 \mathrm{rd}$ centile). The heart sounds were best heard in the right chest, with a pansystolic murmur at the right sternal margin and a loud pulmonary second sound. The right hemithorax was under-developed and immobile. There were pedunculated accessory auricles along the line from the tragus to the angle of the mouth on both sides. Congenital heart disease with dextro-cardia due to right pulmonary atelectasis was diagnosed.

A chest radiograph showed displacement of the mediastinum to the right and no aeration of the right lung (Fig. 1). Abdominal radiographs were normal. An ECG showed left ventricular hypertrophy with marked axis rotation. Cardiac catheterization, via the inferior vena cava, revealed pulmonary hypertension and a patent ductus arteriosus with bi-directional shunting. Angiocardiography demonstrated a single left pulmonary artery continuous with the parent trunk. The right pulmonary artery was atretic (Fig. 2). A small sequestrated right 


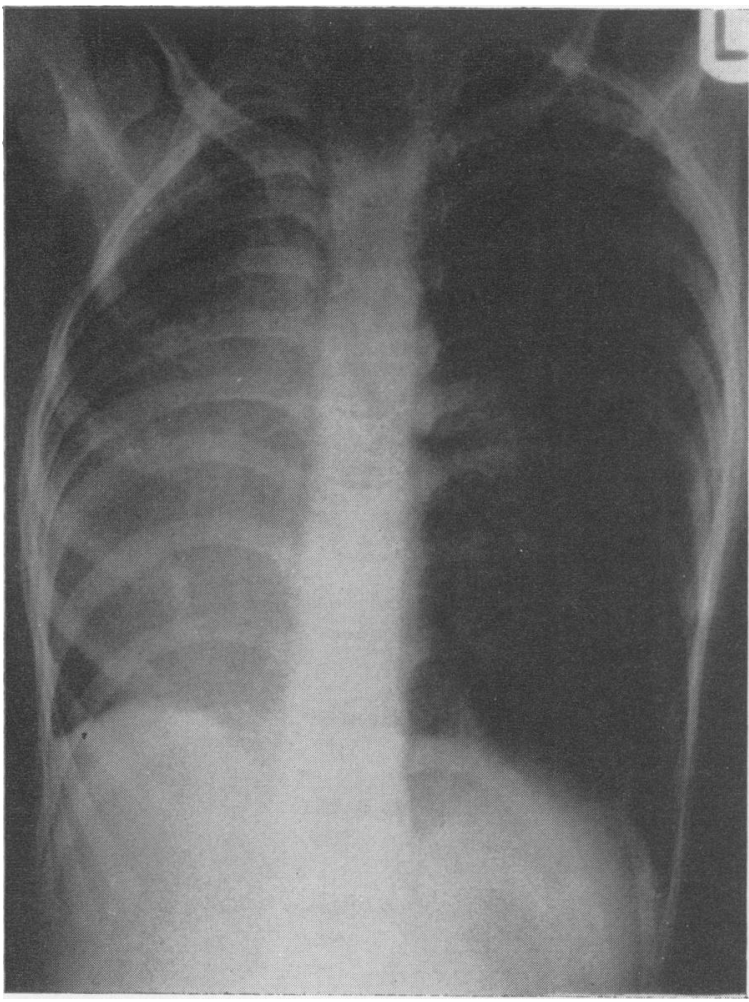

FIG. 1. Chest radiograph at age $10 \frac{1}{2}$ years, showing the mediastinum shifted into the right hemithorax with marked crowding of the right ribs.

lower lobe received its arterial supply from the descending aorta. The pyelographic films demonstrated a horse-shoe kidney with the right half displaced towards the left.

At the age of 5 years she was noted to have underdevelopment of the right half of her mandible, with crowding of the lower incisors, and a high arched palate. At the age of 12 years the jaw deformity had become marked with shifting of the midline of the mandible to the right, causing malocclusion. The facial asymmetry with the accessory auricles and a swelling over the upper eyelid made her acutely conscious of her appearance. A hard, nodular and slightly tender swelling had appeared over the outer canthus of the right eye measuring $1 \times 1 \times 0.5 \mathrm{~cm}$. It was mobile and not attached to the skin.

On 6 December, 1973 this swelling and the accessory auricles were removed for cosmetic reasons. The cyst shelled out easily and on section gave a gritty sensation. The cut surface had a chalky white appearance. The microscopic appearance was typical of a calcifying epithelioma of Malherbe (Fig. 3).

\section{Discussion}

Oculoauriculovertebral dysplasia is not a well known syndrome. It is not hereditary (Gorlin et al., 1963). The diagnosis in this case was delayed until the age of 12 years because not all the usual features were present. The bony anomalies affect the vertebral column in the form of hemi-vertebrae, abnormal segmentation or fusion and supernumerary vertebrae. These are probably the result of anomalous mesoblastic development possibly of vascular origin (Magalini, 1971). In this child the only primary skeletal anomalies were hemi-mandibular hypoplasia and a high arched palate; hypoplasia of the right ribs was secondary to pulmonary aplasia. Since vertebral anomalies are not always present, the name Goldenhar's syndrome is preferable to oculoauriculovertebral dysplasia.

The congenital malformations of the face affect the structures developing from the first and second branchial arches, the first pharyngeal pouch and the first branchial cleft (Berkman and Feingold, 1968). The first branchial arch is very vulnerable from the third to the fifth week of intrauterine development, the period between the disappearance of the first aortic arch and the full development of the external carotid artery, when its blood supply is maintained by the small stapedial artery (McKenzie, 1958).

Oral manifestations include a high arched or cleft palate, macrostoma micrognathos, maxillary hypoplasia and unilateral hypoplasia of the mandible. The last may not be present at birth but develops later as in this child in whom it was first noted at 5 years. It increases the facial disfigurement and causes malocclusion. Bilateral auricular appendages, located along the line of fusion of the maxillary and mandibular processes from the tragus to the angle of the mouth are constant findings (Gorlin et al., 1963, Berkman and Feingold, 1968). They may be single and sessile but are more often multiple and pedunculated. The other ear defects are microtia, atresia or stenosis of the external auditory meatus and pre-auricular sinuses. This girl had a calcifying epithelioma above the right outer canthus. The main clinical features of a calcifying epithelioma are hardness and attachment to the skin (Temple, 1951). This lesion was originally described by Malherbe and Chenantais (1880) as a calcified epithelioma of sebaceous glands. Cote (1936), has pointed out that in French epithelioma simply means an epithelial tumour and the term does not, as in English, imply malignancy. The origin of these lesions has been attributed to hair matrix cells (Highman and Ogden, 1944), early cell lines (Lever and Griesemer, 1949) and degeneration of the hyperplastic lining of an epidermoid cyst (Willis, 1953). Histologically, transition between the basaloid cells and the degenerate epithelium is common and there are obvious 


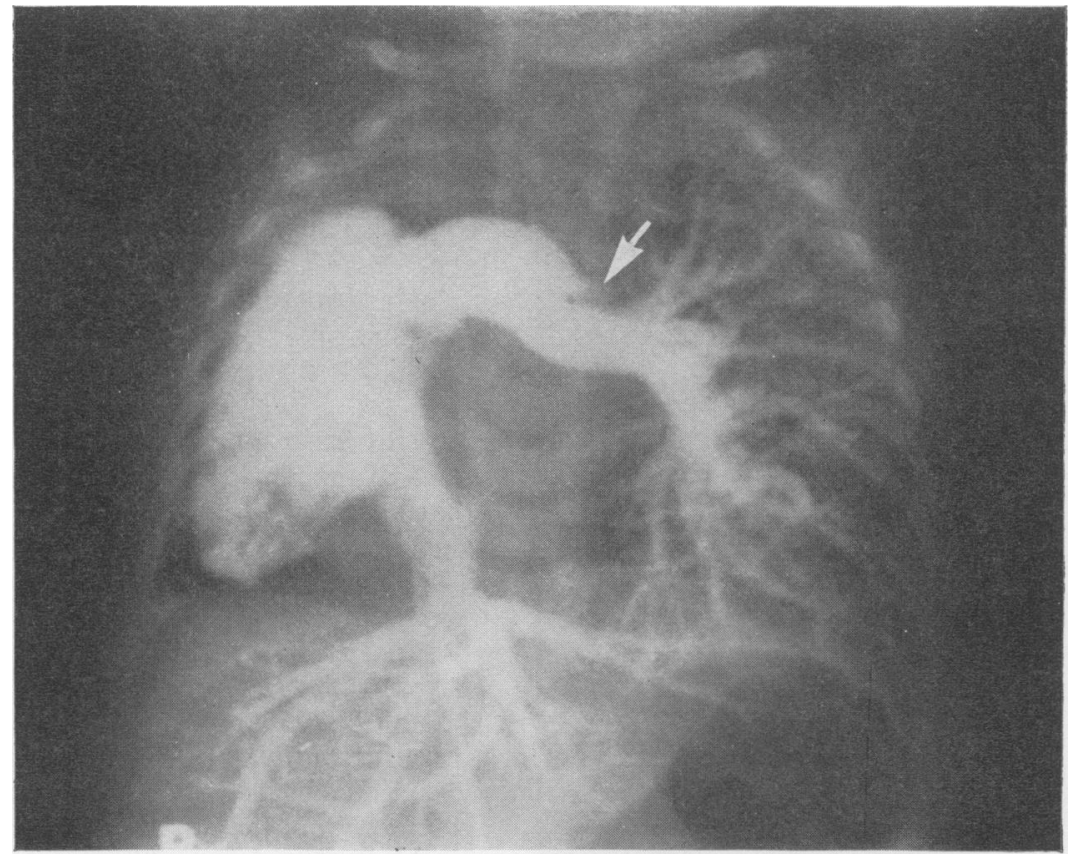

FIG. 2. Angiocardiogram showing the inferior vena cava, hepatic veins, right ventricle and pulmonary trunk. The atretic right pulmonary artery is arrowed.

Fig. 3. Section showing shadow cells with calcification below and to the left. To the right are giant cells, a few basaloid cells and stroma $(\mathrm{HE} \times 70)$. 
resemblances between calcifying epitheliomas and epidermoid cysts in encapsulation, subcutaneous location, and anatomical distribution (Hurley, 1955). Dermoid and epidermoid cysts, often epibulbar, are common in Goldenhar's syndrome and the occurrence of a calcifying epithelioma in this child supports Willis's now generally accepted theory.

In reviewing the aetiology of agenesis of the lung, Hurwitz and Stephens (1937) suggested that it might be secondary to maldevelopment of the pulmonary vascular system. The angiocardiographic findings in this case support this and the hypothesis that the lesions in Goldenhar's syndrome are primarily vascular in origin.

Booth and Berry (1967) reviewed eighteen cases of unilateral pulmonary agenesis and found that six or eight living patients had ipsilateral facial abnormalities. This case is a further example of the correlation of pulmonary agenesis with facial abnormalities on the same side, with, in addition, the bilateral pre-auricular appendages typical of Goldenhar's syndrome.

The majority of cases of pulmonary agenesis have been recorded in young infants diagnosed shortly before their death or at post-mortem but the condition is compatible to a full span of life (Field, 1946).

The girl, now 12 years old, is leading a comparatively normal life in spite of her single lung and patent ductus arteriosus with pulmonary hypertension.

\section{Acknowledgments}

We wish to thank Dr R. A. Risdon, Senior Lecturer in Histopathology, at the Hospital for Sick Children, Great
Ormond Street, London for his help; Dr K. M. Cameron, Consultant Pathologist at St Peter's Hospitals, London for photography of the histopathology specimens and Mr R. E. Bartholomew for the illustrations.

\section{References}

Berkman, M.D. \& Feingold, M. (1968) Oculoauriculovertebral dysplasia (Goldenhar's syndrome). Oral Surgery, Oral Medicine and Oral Pathology, 25, 408.

BOOTH, J.B. \& BERRY, C.L. (1967) Unilateral pulmonary agenesis. Archives of Disease in Childhood, 42, 361.

COTE, F.H. (1936) Benign calcified epithelioma of the skin. Journal of Pathology, 43, 575.

FIELD, C.E. (1946) Pulmonary agenesis and hypoplasīa. Archives of Disease in Childhood, 21, 61.

GoldenhaR, M. (1952) Associations malformatives de l'oeil et de l'oreille, en particulier le syndrôme dermoïde épibulbaire - appendices auriculaires-fistula auris congenita et ses relations avec la dysostose mandibulofaciale. Journal de Génétiyue Humaine, 1, 243.

Gorlin, R.J., KenNeth, L.J., JaCoBsen, U. \& GoldschSCHміDт, E. (1973) Oculoauriculovertebral dysplasia. Journal of Pediatrics, 63, 991.

Highman, B. \& Ogden, G.E. (1944) Calcified epithelioma. Archives of Pathology, 37, 169.

HuRLEY, J.V. (1955) Calcified epithelioma of Malberbe. Australian and New Zealand Journal of Surgery, 24, 207.

Hurwitz, S. \& Stephens, H.B. (1937) Agenesis of the lung. A review of the literature and report of a case. American Journal of Medical Sciences, 193, 81.

Lever, W.F. \& Griesemer, R.D. (1949) Calcifying epithelioma of Malherbe. Archives of Dermatology, 59, 506.

Magalini, S. (1971) Dictionary of Medical Syndromes, 1st Edn, pp. 197-219. J. P. Lippincott Co., Philadelphia.

Malherbe, A. \& Chenantais, J. (1880) Note sur l'épithéliome calcifié des glandes sébacées. Bulletins et mémoires de la Société d'anatomie de Paris, 15, 169.

McKenzie, J. (1958) The first arch syndrome. Archives of Disease in Childhood, 33, 477.

TEMPLE, J.L. (1951) Benign concified epithelioma. British Medical Journal, 1, 920.

Willis, R.A. (1953) Pathology of Tumours, 2nd Edn, p. 271. Butterworths, London. 